\title{
19. RADIOLARIANS FROM THE WEST FLANK OF REYKJANES RIDGE, LEG 49 OF THE DEEP SEA DRILLING PROJECT
}

\author{
Hsin Yi Ling, ${ }^{1}$ Department of Oceanography, University of Washington, Seattle, Washington
}

\section{INTRODUCTION}

Leg 49 of the Deep Sea Drilling Project (DSDP), 18 July to 4 September, 1976, was designed to study the crustal formational process in the North Atlantic Ocean (Figure 1). Among eight sites drilled, significant amounts of Miocene sediments rich in siliceous microfossils were recovered at Sites 407 and 408 in the Reykjanes Ridge area. Radiolarians from these cored sediments are discussed in this report.

Originally, three sites, 407 through 409 , on a latitudinal transit near Iceland, were proposed for study of (1) the history of the Iceland hot spot and its associated geochemical anomaly; (2) evidence for hydrothermal alteration of oceanic crust in transverse of the Mid-Atlantic Ridge; and (3) evidence of aging effects in the ocean crust, and the history of glaciation in North Atlantic (Luyendyk, Cann, et al., 1977).

The high-latitude radiolarians from the area were reviewed recently in detail by Bjorklund (1976). One of the earlier works by Ehrenberg (1861) dealt with this area; he recognized 24 and 28 taxa, respectively, from his samples 7 and 8 , which were from slightly south of DSDP Sites 407 and 408 .

Judging from the oceanographic condition of the area, a close relationship can be expected between the two sites under consideration and those in the adjacent areas, with regard to assemblage composition and faunal succession.

Therefore, objectives of the present investigation are to compare the radiolarian successions at the two sites, and to relate Neogene radiolarian biostratigraphy with those of the middle- and high-latitude regions of the North Atlantic.

\section{MATERIAL STUDIED}

Sediment samples from Sites 407 and 408 were selected on the basis of initial core descriptions for the respective sites, from the shipboard summary provided by Dr. Richard $\mathrm{Z}$. Poore. The method of sample preparation was the same as that of previous investigations (Ling, 1973, 1975).

Relative abundances of taxa within assemblages and preservation states of these microfossils are generally given according to the shipboard format for paleontology and biostratigraphy; for abundance: + (single specimen), R (rare), F (few), C (common), and A (abundant); for preservation: $\mathrm{P}$ (poor), M (moderate), and G (good).

All slides used for this investigation will be deposited permanently in the micropaleontology collection, Department of Oceanography, University of Washington.

${ }^{1}$ Present address: Department of Geology, Northern Illinois University, DeKalb, Illinois.

\section{TAXONOMIC LIST}

Most of the radiolarian species encountered during this investigation have already been discussed recently by various workers, and some forms have undergone considerable taxonomic revision, which I feel needs careful scrutiny before it is accepted. Such is beyond the scope of this investigation. In what follows, therefore, species are listed in alphabetical order, and for those forms the original names are retained.

Polycystines:

Anomalacantha dentata (Mast), Benson, MS, p. 170, pl. 5, fig. 10, $11=$ Heteracantha dentata Mast, 1910, p. 159.

Artostrobus annulatus (Bailey), Haeckel, 1887, p. $1481=$ Cornutella ? annulata Bailey, 1856, p. 3, pl. 1, fig. 5a, b.

Ceratocyrtis mashae Bjorklund, 1976, p. 1125, pl. 17, fig. 1-5

Clathrocyclas craspedota (Jorgensen), Jorgensen, 1905, p. 139, pl. 17, fig. 98-100 = Theocalyptra craspedota Jorgensen, 1900, p. 85 .

Cornutella hexagona Haeckel, 1887, p. 1180, pl. 54, fig. 9.

Cornutella profunda Ehrenberg, 1859 , p. $31=$ Cornutella clathrata $\beta$ profunda Ehrenberg, 1856, pl. 35B, fig. 21.

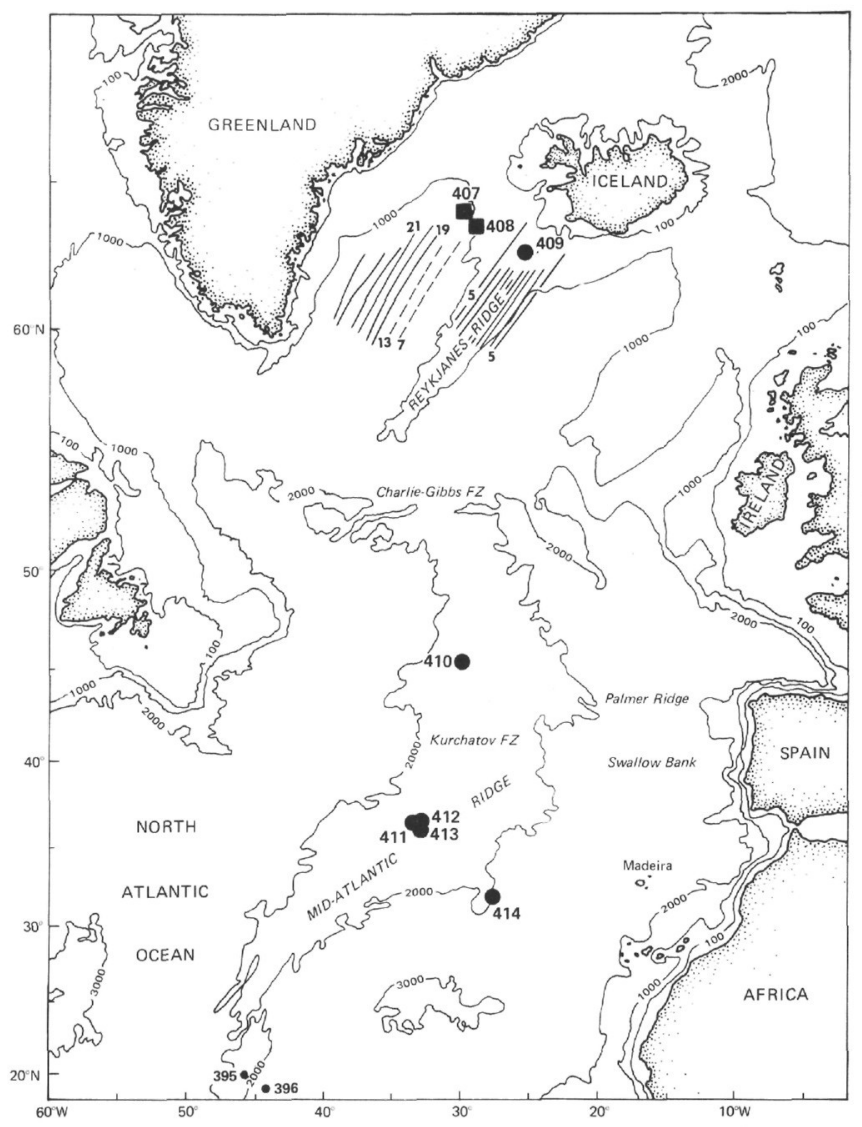

Figure 1. Index map of the North Atlantic Ocean showing sites drilled during Leg 49 (circle) and the core sediments treated in this paper (square). Magnetic lineation near Reykjanes Ridge is from Pitman et al. (1974). 
Cromyechinus borealis (Cleve), Jorgensen, 1905, p. 117, 118, pl. 8, fig. 35, pl. 9, fig. 36, $37=$ Actinomma boreale Cleve, 1899, p. 26, pl. 1, fig. $5 \mathrm{~b}, \mathrm{c}$ (only).

Cycladophora davisiana davisiana Ehrenberg, Petrushevskaya, 1967, p. 122-124, fig. $69,1-7=$ Cycladophora ? davisiana Ehrenberg, 1862, p. 297.

Cycladophora davisiana cornutoides (Petrushevskaya) $=$ Cycladophora davisiana var. cornutoides Petrushevskaya, 1967, p. 124, fig. 70, 1-3 $=$ Theocalyptra davisiana cornutoides (Petrushevskaya), Kling, 1977, p. 217 , pl. 1, fig. 20 .

Cyrtocapsella cornuta Haeckel, 1887, p. 1513, pl. 78, fig. 9.

Cyrtocapsella eldholmi Bjorklund, 1976, p. 1125, 1126, pl. 17, fig. 11-13.

Cyrtocapsella japonica (Nakaseko), Sanfilippo and Riedel, 1970, p. 452, pl. 1, fig. 13-15 = Eusyringium japonicum Nakaseko, 1963, p. 193, pl. 4, fig. 1-3.

Cyrtocapsella tetrapera Haeckel, Sanfilippo and Riedel, 1970, p. 453, pl. 1, fig. $16-18=$ Cyrtocapsa tetrapera Haeckel, 1887, p. 1512.

Dictyocryphalus papillosus (Ehrenberg), Nigrini, 1967, p. 63, 64, pl. 6, fig. 6 = Eucyrtidium papillosum Ehrenberg, 1872, p. 310 .

Dictyophimus gracilipes Bailey, 1856, p. 4, pl. 1, fig. 8.

Echinomma leptodermum Jorgensen, 1900, p. 57; 1905, p. 116, pl. 8, fig. 33 a-c.

Euchitonia furcata Ehrenberg, 1861, p. 767.

Eucyrtidium tumidulum Bailey, 1856, p. 4, pl. 1, fig. 11.

Heliodiscus asteriscus Haeckel, 1887, p. 445, pl. 33, fig. 8.

Helotholus histricosa Jorgensen, 1905, p. 137, pl. 16, fig. 86-88.

Hymeniastrum euclidis Haeckel, 1887, p. 531, pl. 43, fig. 13.

Lithelius minor Jorgensen, 1900, p. 65, 66, pl. 5, fig. 24.

Lithomelissa stigi Bjorklund, 1976, p. 1125, pl. 15, fig. 12-17.

Lithomitra arachnea (Ehrenberg), Riedel, 1958, p. 242, 243, pl. 4, fig. 7 , 8 = Eucyrtidium lineatum arachneum Ehrenberg, 1862, p. 299

Lithomitra lineata (Ehrenberg), Cleve, 1900, p. 30, pl. 2, fig. $7=$ Lithocampe lineata Ehrenberg, 1839, p. 130.

Lithopera renzae Sanfilippo and Riedel, 1970, p. 454, pl. 1, fig. 21-23, 27.

Phorticium clevei (Jorgensen), Petrushevskaya, 1967, p. 58-62, fig. 32 $1-2 ; 33,1-3 ; 34,1-5=$ Phorticium pylonium Haeckel, Cleve, 1899, $\mathrm{p}$. 31, pl. 3. fig. 2 (not Phorticium pylonium Haeckel, 1887, p. 709, pl. 49, fig. 10).

Spongopyle osculosa Dreyer, 1889, p. 42, pl. 6, fig. 99, 100.

Spongotrochus glacialis Popofsky, 1908, p. 228, 229, pl. 26, fig. 7, 8; pl. 27 , fig. 1 ; pl. 28 , fig. 2 .

Tripyleans:

Eyphysetta nathorstii Cleve, 1899, p. 29, pl. 2, fig. 3 .

Lirella bullata (Stadum and Ling), Ling, 1975, p. 732 , pl. 13, fig. $29=$ Cadium bullatum Stadum and Ling, 1969, p. 484, 485, pl. 1, fig. 9-14.

Lirella mela (Cleve), Ling, 1973, p. 782, pl. 2, fig. $16=$ Beroetta melo Cleve, 1899, p. 27, pl. 1, fig. 8.

Porospathis holostoma (Cleve), Borgert, 1901, p. 48, 49, fig. 56, 56a = Polypetta holostoma Cleve, 1899, p. 32, 33, pl. 3, fig. 4a, 4b.

Protocystis harstoni (Murray), Borgert, 1901, p. 28, 29, fig. $30=$ Challengeria harstoni Murray, 1885, p. 226, pl. A, fig. 14a.

\section{RADIOLARIAN OCCURRENCES AT SITES 407 AND 408}

Site 407 is at $63^{\circ} 56.32^{\prime} \mathrm{N}, 30^{\circ} 34.56^{\prime} \mathrm{W}$, in a water depth of 2472 meters. The site is on the western flank of the Reykjanes Ridge and lies on magnetic anomaly 13 (36 to 38 m.y.) (Figure 1). Coring was continuous through 300 meters of sediments and to a total penetration depth of 458.5 meters, where the hole terminated in basalt.

Site 408 is situated at $63^{\circ} 22.63^{\prime} \mathrm{N}, 28^{\circ} 54.74^{\prime} \mathrm{W}$, in a water depth of 1624 meters; it lies on the topographic high of the west flank of the Reykjanes Ridge, on anomaly 6 (about $20 \mathrm{~m} . y$.). Continuous coring recovered 321 meters of sediments, and penetrated into basaltic lavas with interlayered sedimentary rocks down to 361 meters sub-bottom.

Although these two sites are geographically close together, and are apparently under similar oceanographic regimens, radiolarian faunas recovered show surprisingly significant differences (Tables 1 and 2).

At Site 407, Quaternary glacial and post-glacial marine sediments contain typical high-latitude forms, including Cycladophora davisiana davisiana, and well-preserved diversified tripyleans, some of which have previously been recovered from surface (piston core) sediments of the Norwegian Sea (Reshetnjak, 1969; Stadum and Ling, 1969; Bjorklund, 1976). In sharp contrast to Site 407, however, radiolarians are generally rare at Site 408 , and tripyleans are completely absent from calcareous sandy mud and turbidites of correlative age.

The Pliocene calcareous nannofossil ooze section, Cores 7 through 14 , Site 407 , and Cores 5 through 13 , Site 408, is characterized by the predominance of spongodiscid groups. Unfortunately, these forms are, at least for the time being, rather difficult to apply for biostratigraphic purposes. At Site 408, abundant Clathrocyclas coscinodiscus occurs in 6 meters of siliceous marly ooze (Core 5) of the upper lower Pliocene section.

The initial appearance of Cycladophora davisiana davisiana near the top of the Pliocene sequence from Core 6 at Site 407 and Core 4 at Site 408 may be useful for purposes of correlation of the area. The last appearance of Euchitonia furcata and of Hymeniastrum euclidis occurs slightly below this level.

The presumed "upper" Miocene sequence is characterized by calcareous nannofossil or chalk ooze at both sites. Sediments of this age are rather thin at Site 407, about 20 meters, and the top of Cyrtocapsella tetrapera is found immediately below this sequence, in Sample 18-2, $130-132 \mathrm{~cm}$. On the other hand, at Site 408, sediments of correlative age are rather thick, about 100 meters, and overlie the extinction of Cyrtocapsella tetrapera in Sample $24-1,60-62 \mathrm{~cm}$. Apparently, therefore, at least a significant depositional hiatus can be inferred for Site 407, within Core 17 or between Cores 17 and 18 , which seems to correspond to a lithologic change from calcareous ooze above to siliceous material below.

Siliceous nannofossil chalk characterizes the middle to lower Miocene sequence at each site. Radiolarians are generally abundant and rather well preserved in this section, and include several forms widely known from the low- to middle-latitude regions for such ages: e.g., Cyrtocapsella cornuta, $C$. japonica, C. tetrapera, and Lithopera renzae.

The down-core occurrence of Cyrtocapsella tetrapera continues to between Samples 29-1; 70-72 cm and 29-6, $30-32 \mathrm{~cm}$ of Site 407; at Site 408, the lowermost occurrence is between Samples 33-4, 30-32 cm and 34-2, 50-52 cm.

Underlying these siliceous deposits at Site 407 is a basal sedimentary unit of nannofossil chalk (Core 30) and nannofossil chalk with basaltic pebbles (Cores 31 and 32), above where drilling penetrated into the basaltic lava flows. Although radiolarians are too sporadic for age assignment, the uppermost Oligocene or lowermost Miocene seems plausible at least for the sediments of Cores 30 and 31 , because of the occurrence of a silicoflagellate, Rocella gemma. A radiolarian, "Lychnocanoma" elongata, which generally is characteristic for such age (Ling, 1972), was not observed. For Site 408, no radiolarians were observed in basal sediments of glauconitic marly nannofossil ooze, Core 34 , or in basaltic sand, Core 35 . 
TABLE 1

Radiolarian Species Distribution, Abundance, and Preservation, Site 407

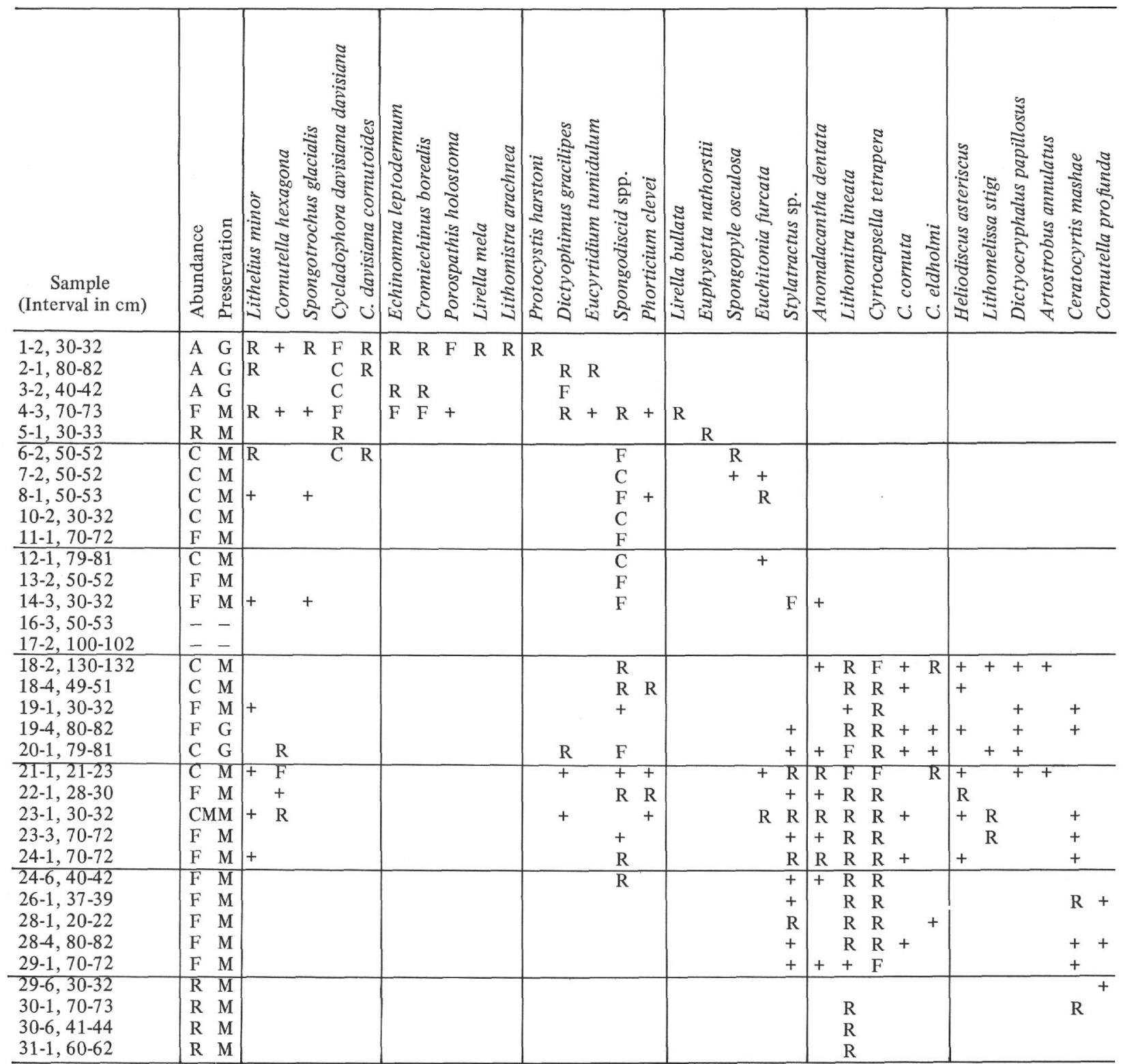

\section{DISCUSSION}

As discussed above, correlation of deep-sea sediments at the two sites is difficult, owing to unexpected yet significant differences in faunal composition between them. It is also difficult to relate radiolarian biostratigraphic successions to those of the adjacent areas.

Benson (1972) observed low- to middle-latitude "warm water' radiolarians at Site 116, DSDP Leg 12, and this enabled him to recognize zones up to the upper Pliocene Spongaster pentas Zone; but this was not the case for my study here, because only a few of these taxa occur up to a part of the upper Miocene. Consequently, no zonation is possible.

To the north, in the Norwegian Sea, Bjorklund (1976) established eight zones in the Neogene section. In comparing the range of radiolarian species there with the Leg 49 samples, some discrepancies in geological occurrence are obvious, and these cause difficulties in applying his zonal scheme directly. For example, some key species used in the Norwegian Sea sediments are either completely absent - e.g., Antarctissa whitei - or possess different ranges - e.g., Cycladophora davisiana and Spongotrochus glacialis.

A consistent occurrence of Cyrtocapsella tetrapera in middle and lower Miocene sections of two sites deserves special attention. This is one of a few species which have been recorded generally from low- to middle-latitude regions of the world oceans. Bjorklund (1976) recorded its limited occurrence in Norwegian Sea Sites 338 and 342, the northernmost occurrence for this species in the North Atlantic deep-sea sediments thus far reported (Figure 2). In 
TABLE 2

Radiolarian Species Distribution, Abundance and, Preservation, Site 408

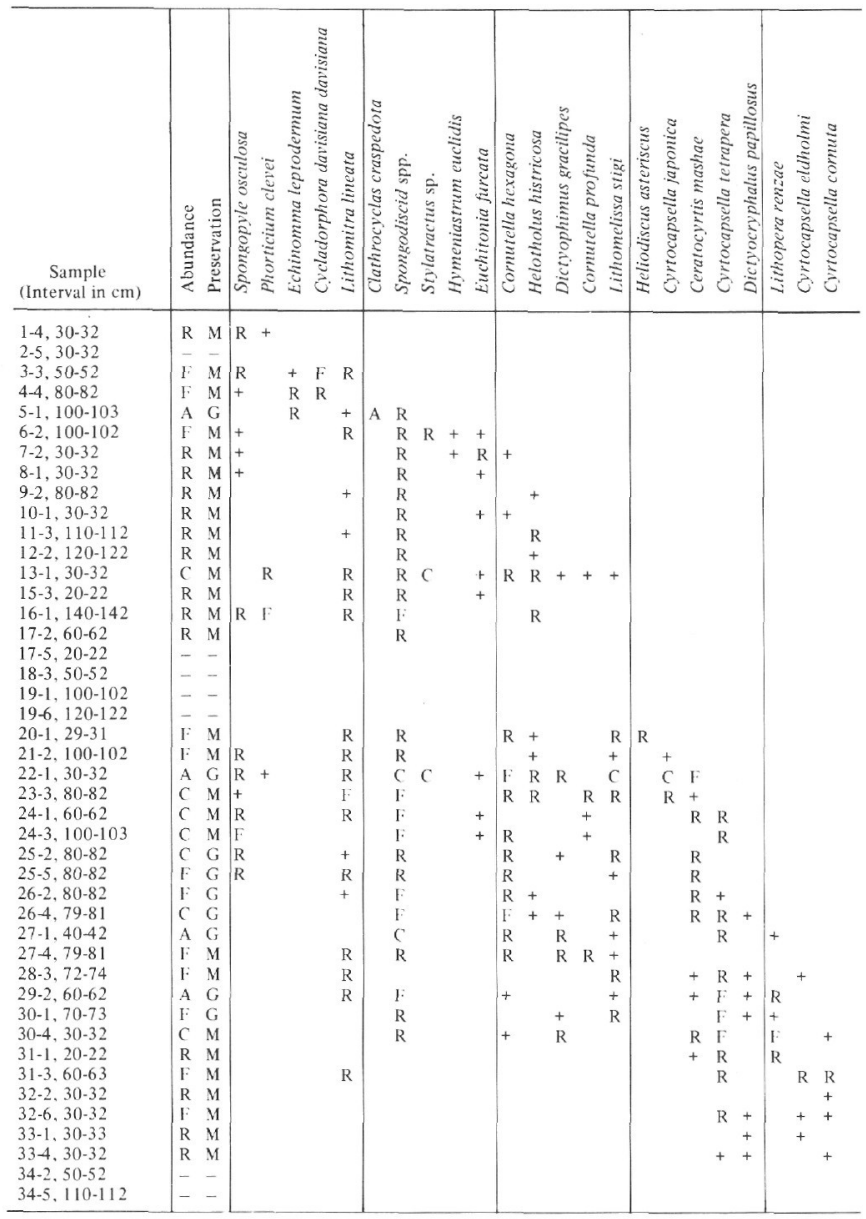

comparing the limited geological distribution of the species from Site 338, Sections 10-1 through 11-1 (Bjorklund, 1976, Table 8, p. 1111) with biostratigraphic zonation of other groups of planktonic microfossils (Schrader et al., 1976, p. 1198, 1199), the range of Cyrtocapsella tetrapera in the Norwegian Sea is within the upper part of the Corbisema triacantha (silicoflagellate) Zone, or the upper part of the Actinomma holtedahli Zone to the lower part of the Lithomelissa stigi (radiolarian) Zone. Note here that although Schrader et al. (1976, p. 1208) stated that "initial appearance of Cyrtocapsella tetrapera is found in Sample 338-18, CC, ' which would place it at the basal part of the lower Miocene, such occurrence was not recorded in Bjorklund's species distribution chart (1976, table 8). Thus, the "middle" to "lower" Miocene sequences containing Cyrtocapsella tetrapera, Cores 18 through 29 of Site 407 and Cores 24 through 32 of Site 408, can be correlated approximately with the Actinomma holtedahli to Lithomelissa stigi zones in the Norwegian Sea of Bjorklund.

Finally, a few remarks can be made concerning paleoecology of the deep-sea sediments of the area. Radiolarians in the Quaternary section generally consist of those previously reported in surface sediments and plankton samples from the area; this indicates that the oceanographic condition in the area was in general the same as that of the present day. One significant difference between fauna at the two sites is the complete absence of tripyleans in the Site 408 sediments.

Biostratigraphically, the oldest occurrence of Cycladophora davisiana davisiana subsequent to the last occurrence of Euchitonia and Hymeniastrum specimens in the area may be regarded as a signal of an oceanographic and climatic change from warmer Tertiary time to the present-day condition. This change is reflected between Cores 6 and 7 of Site 407 and Cores 4 and 5 of Site 408, the lower part of foraminiferal zone 21 (Richard Z. Poore, personal communication); this seems to accord with the beginning of major glaciation in the North Atlantic about 3 m.y. ago, on the basis of data from Leg 12 (Berggren, 1972).

The Pliocene sequence at both sites is characterized by abundant spongodiscid forms, but the depositional environment is less clear from the examined radiolarian data alone.

The Miocene section at these two sites seems to suggest a warm-water depositional condition, inferred from the occurrences of forms which have been widely observed in low to middle latitudes of the North Pacific and North Atlantic. Undoubtedly their occurrence in such a high-latitude region in the North Atlantic can be ascribed to the presence of a northward-flowing warm current, "the Gulf Stream,"' at that time.

\section{ACKNOWLEDGMENTS}

My special thanks are extended to Dr. Richard Z. Poore who, with the consent of co-chief scientists of DSDP Leg 49, invited me to undertake this study and provided me with some pertinent data from the shipboard report, and to the DSDP Curator and Sample Distributional Panel for their unparalleled speedy approval and provision of the requested samples. The operation of DSDP/IPOD has been funded through the National Science Foundation.

I am also indebted to Kozo Takahashi and June Ralstrum; only through their able assistance could this study have been completed at this time.

The study was carried out during the tenure of NSF Grant OCE 75-20434

This is contribution No. 1022 from the Department of Oceanography, University of Washington.

\section{REFERENCES}

In the following, only those references cited in the text are presented. For those dealing with taxonomy, the reader is referred to papers published in the Initial Reports of the Deep Sea Drilling Project, particularly Bjorklund (1976) and Benson (1972).

Benson, R.N., 1972. Radiolaria, Leg 12, Deep Sea Drilling Project. In Laughton, A.A., Berggren, W.A., et al., Initial Reports of the Deep Sea Drilling Project, v. 12: Washington (U.S. Government Printing Office), p. 1085-1113.

Berggren, W.A., 1972. Late Pliocene-Pleistocene glaciation. In Laughton, A. A., Berggren, W.A., et al., Initial Reports of the Deep Sea Drilling Project, v. 12: Washington (U.S. Government Printing Office), p. 953-963.

Bjorklund, 1976. Radiolaria from the Norwegian Sea, Leg 38 of the Deep Sea Drilling Project. In Talwani, M., Udintsev, G., et al., Initial Reports of the Deep Sea Drilling Project, v. 38: Washington (U.S. Government Printing Office), p. 1101-1168. 
Ehrenberg, C.G., 1861. Über die Tiefgrund-Verhältnisse des Oceans am Ein gange der Davisstrasse und bei Island, Monatsber. Kgl. Preuss. Akad. Wiss. Berlin, Jahrg. 1861, p. 275-315.

Ling, H.Y., 1972. Upper Cretaceous silicoflagellates and ebrideans, Am. Paleontol. Bull., v.62, p. 155-229.

1973. Radiolaria: Leg 19 of the Deep Sea Drilling Project. In Creager, J.S., Scholl, D.W., et al., Initial Reports of the Deep Sea Drilling Project, v. 19: Washington (U.S. Government Printing Office), p. 777-797. , 1975. Radiolaria: Leg 31 of the Deep Sea Drilling Project. In Karig, E.D., Ingle, J.C., Jr., et al., Initial Reports of the Deep Sea Drilling Project, v. 31: Washington (U.S. Government Printing Office), p. 703-761.

Luyendyk, B., Cann, J.R., et al., 1977. "Young and hot", drilling, Geotimes, v. 22 , p. 25-28.
Pitman, W.C., III., Larson, R.L., and Herron, E.M., 1974. Age of the ocean basins determined from magnetic anomaly lineations, Geol. Soc. Am. (2 sheets and text).

Reshetnjak, V.V., 1969. Radiolarians of the order Phaeodaria in Recent bottom sediments and in ancient sediments. In Iskopaemye i Sovremennye Radiolyarii. Lvovskoe Geol. Obshchestro, Lvovskogo Univ. Publ., p. 133-140.

Schrader, H.J., et al., 1976. Cenozoic biostratigraphy, physical stratigraphy and paleooceanography in the NorwegianGreenland Sea, DSDP Leg 38 Paleontological synthesis. In Talwani, M., Udintsev, G., et al., Initial Reports of the Deep Sea Drilling Project, v. 38: Washington (U.S. Government Printing Office), p. 1197-1211.

Stadum, C.J., and Ling, H.Y., 1969. Tripylean Radiolaria in deep-sea sediments of the Norwegian Sea, Micropaleontology, v. 15, p. $481-489$. 


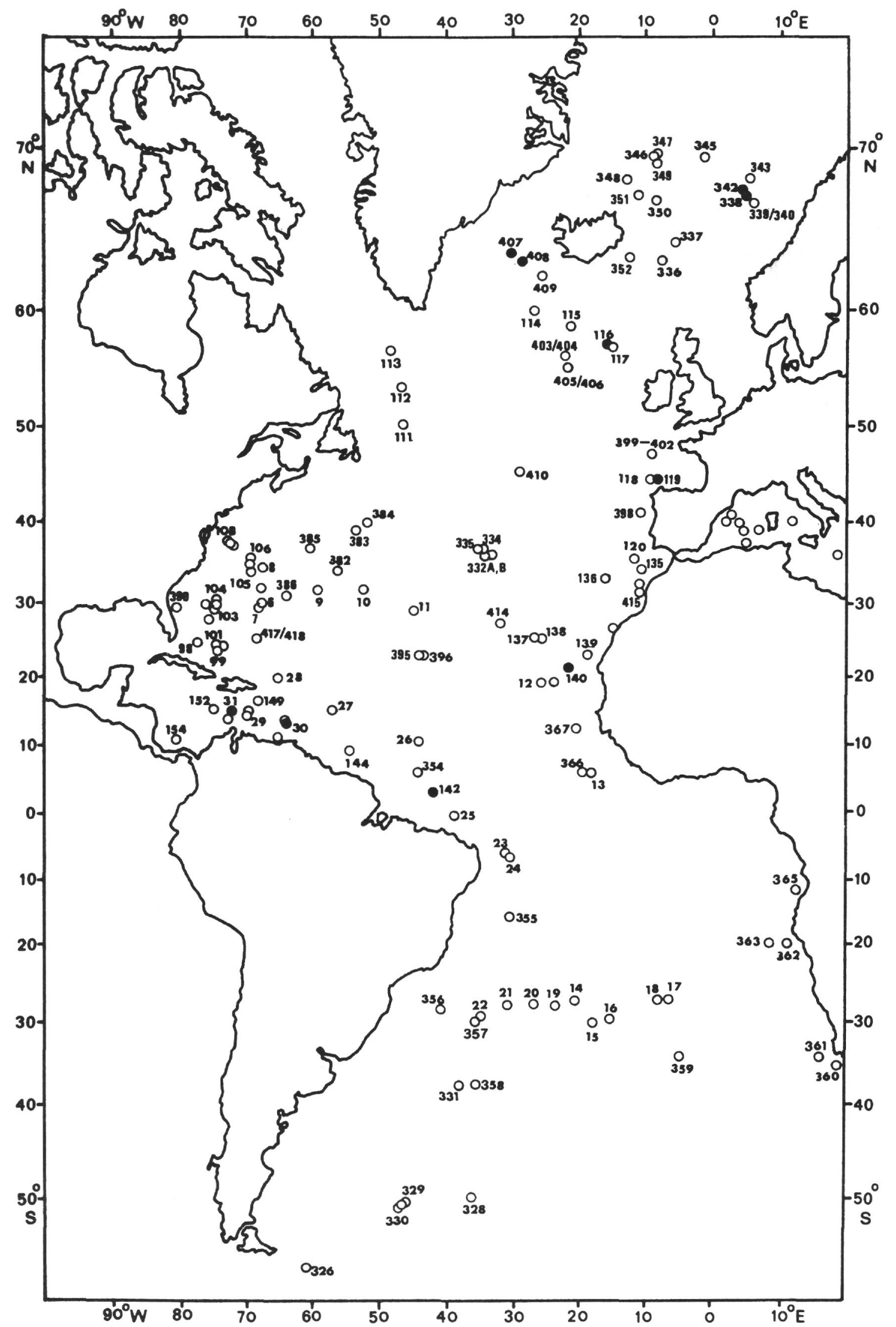

Figure 2. Reported occurrence of Cyrtocapsella tetrapera from submarine deposits of DSDP sites (filled circle) in the North Atlantic. 